\title{
Orthodontic bonding to porcelain surfaces: In vitro shear bond strength
}

\section{Colagem de acessórios ortodônticos a superfícies de porcelana: resistência ao cisalhamento in vitro}

\begin{abstract}
Purpose: To evaluate in vitro the shear bond strength of orthodontic accessories to porcelain, under different porcelain surface treatment protocols, and the resultant failure pattern after debonding.

Methods: The sample consisted of 80 feldspathic porcelain discs, divided into 4 groups: Group 1 - 37\% Phosphoric acid etching; Group 2 - 10\% fluorhydric acid; Group 3 - 37\% Phosphoric acid and silane application; Group 4 - 10\% fluorhydric acid and silane application. The samples were submitted to the shear bond strength test in a universal test machine to record the maximum rupture force.

Results: Group 1 showed lower results, and Group 4 presented higher results than the other tested groups. There was no statistical difference between Groups 2 and 3. Groups 1 and 3 presented exclusively adhesive failures between porcelain and resin, whereas Groups 2 and 4 showed cohesive failures in porcelain.

Conclusion: The use of phosphoric acid followed by silane application was the best protocol for bonding orthodontic accessories to porcelain surfaces, since it was capable of resisting the forces applied during orthodontic treatment without causing irreversible failures in restorations.
\end{abstract}

Key words: Shear bond strength; dental porcelain; dental bonding; Orthodontics

\section{Resumo}

Objetivo: Avaliar, in vitro, a resistência ao cisalhamento de acessórios ortodônticos colados à porcelana, sob diferentes protocolos de adesão, e o padrão de falha resultante após a descolagem desses acessórios.

Metodologia: A amostra foi composta de 80 pastilhas de porcelana feldspática, divididas em 4 grupos: Grupo 1 - Ácido fosfórico a 37\%; Grupo 2 - ácido fluorídrico a 10\%; Grupo 3 - ácido fosfórico a 37\% e silano; Grupo 4 - ácido fluorídrico a 10\% e silano. A amostra foi submetida a teste de cisalhamento em máquina de ensaios universal para registro da força máxima de ruptura.

Resultados: $\bigcirc$ grupo 1 teve resultados inferiores aos demais grupos testados, bem como o grupo 4 apresentou resultados superiores. Não houve diferença entre os grupos 2 e 3 . Os grupos 1 e 3 apresentaram falhas exclusivamente de caráter adesivo entre porcelana e resina, enquanto que nos grupos 2 e 4 registrou-se a ocorrência de falhas coesivas em porcelana.

Conclusão: Conclui-se que a utilização de ácido fosfórico e silano representa o melhor protocolo de adesão de acessórios ortodônticos a superfícies de porcelana, uma vez que é capaz de resistir às forças aplicadas durante o tratamento ortodôntico sem causar falhas irreversíveis à restauração.

Palavras-chave: Resistência ao cisalhamento; porcelana dentária; colagem dentária; ortodontia

\author{
Magáli Beck Guimarães a \\ Helen Fernandes Lenz ${ }^{a}$ \\ Rodrigo Salbego Bueno ${ }^{b}$ \\ Micéli Beck Guimarães Blaya ${ }^{c}$ \\ Luciana Mayumi Hirakata c
}

\begin{abstract}
- School of Dentistry, Centro Universitário Franciscano (UNIFRA), Santa Maria, RS, Brazil b SOERGS, Porto Alegre, RS, Brazil

c School of Dentistry, Pontifical Catholic University of Rio Grande do Sul, Porto Alegre, RS, Brazil
\end{abstract}

\author{
Correspondence: \\ Magáli Beck Guimarães \\ Curso de Odontologia \\ Centro Universitário Franciscano \\ Rua dos Andradas, 1614 - Centro \\ Santa Maria, RS - Brasil \\ 97010-032 \\ E-mail: magaliguimaraes@gmail.com
}

Received: September 29, 2011

Accepted: December 13, 2011

Conflict of Interests: The authors state that there are no financial and personal conflicts of interest that could have inappropriately influenced their work.

Copyright: (C) 2011 Guimarães et al.; licensee EDIPUCRS. This is an Open Access article distributed under the terms of the Creative Commons AttributionNoncommercial-No Derivative Works 3.0 Unported License. 


\section{Introduction}

Contemporary orthodontics has paid special attention to treatment in adults, in view of the considerable increase in demand by these patients, observed in clinical dentistry. As a result, one of the problems frequently found by dentists concerns orthodontic accessory bonding to teeth with esthetic restorations, such as laminates and porcelain crowns, which are commonly performed to restore esthetically or functionally damaged teeth (1). Nowadays, ceramics are considered the material of choice for indirect restorations, particularly because of the advantages they offer, such as biocompatibility, high compressive strength and resistance to abrasion, chemical and color stability, radiopacity and excellent potential for simulating the appearance of natural teeth (2-4).

In cases of patients who have porcelain dental restorations and require orthodontic treatment, a dilemma arises: If on the one hand, an optimum bond strength is desired to minimize failures due to accessory debonding during the treatment period, on the other, porcelain must return to its initial state of polishing and appearance, without any damage to its surface after accessories are removed (1).

There are many protocols proposed in the literature for bonding orthodontic accessories to porcelain surfaces, and they vary right from the different acids applied for various periods of time through to airborne particle abrasion or application of bonding agents such as silane. Although there are innumerable protocols for bonding orthodontic accessories to porcelain, there is still no scientific consensus about which of the techniques would be the ideal standard protocol for the purpose of overcoming the two points of contrast mentioned above (5).

The aim of this study was to evaluate the in vitro shear bond strength of orthodontic accessories to porcelain, under different porcelain surface treatment protocols, and the resultant failure pattern after debonding these accessories.

\section{Material and methods}

The sample consisted of 80 feldspathic porcelain discs (Noritake EX-3, Noritake, Japan), fabricated by the agglutination of powder and distilled water in a circular two-piece matrix with a central perforation $5 \mathrm{~mm}$ in diameter and $3 \mathrm{~mm}$ thickness (Laboratório de Prótese Dentária Oficina do Dente, Porto Alegre, RS, Brazil). With the aid of a soft paintbrush, small portions of the powder/liquid mixture were compacted into the matrix that was placed on a glass plate, until it was completely filled. After this the disc was removed with the aid of an extractor, and taken to the oven (Vulcano, EDG Equipamentos e Controle, São Carlos, SP, Brazil) for sinterization, at temperatures and for time intervals in accordance with the manufacturer's instructions After sinterization and cooling to room temperature, all the porcelain discs were individually embedded in PVC tubes ( $20 \mathrm{~mm}$ in diameter and $20 \mathrm{~mm}$ high), with pink selfpolymerizing acrylic resin (JET, Clássico, São Paulo, SP, Brazil), leaving one of the disc surfaces exposed and level with the top part of the PVC tube, so that the set could be correctly position in the test machine.

Finishing was performing with 400-, 600- and 1200-grit water abrasive papers, under cooling in a low speed turbine for 10 seconds. Final polishing was performed with the Edenta System for Porcelain Polishing, composed of three burs of different colors used sequentially in the following order: white, pink and gray (EXA Cerapol 0352 and 0394, Cerapol Super 0374, Edenta, Switzerland), in a low speed turbine, without cooling, for 5 seconds, each. The finishing material was renewed after every three samples and the polishing material after every 10 samples.

The sample was randomly divided into four groups of 20 test specimens - the minimum number recommended for testing debonding strength (6). Lingual buttons (ref. 3010205, Morelli Ortodontia, São Paulo, Brazil) were bonded to the porcelain disk surfaces, using different porcelain surface treatment protocols, which characterized the different research groups, as follows:

- Group 1 (G1): Etching the porcelain surface with 37\% phosphoric acid (Condac 37\%, FGM Produtos Odontológicos, SC, Brazil) for 60 seconds;

- Group 2 (G2): Etching the porcelain surface with $10 \%$ fluorhydric acid (Condac 37\%, FGM Produtos Odontológicos, SC, Brazil) for 60 seconds;

- Group 3 (G3): Etching the porcelain surface with 37\% phosphoric acid (Condac 37\%, FGM Produtos Odontológicos, SC, Brazil) for 60 seconds, followed by silane application (Prosil, FGM Produtos Odontológicos, SC, Brazil);

- Group 4 (G4): Etching the porcelain surface with 10\% fluorhydric acid (Condac 37\%, FGM Produtos Odontológicos, SC, Brazil) for 60 seconds, followed by silane application (Prosil, FGM Produtos Odontológicos, SC, Brazil).

After surface treatment, the adhesive system and resin composite (Transbond XT, 3M ESPE Dental Products, California, USA) were applied to every sample. Bonding was performed by the same operator, with the aid of a bonding forceps with the same bond force as routine clinical bonding, and excess resin was removed with an exploratory probe. In all the samples, the polymerization process was performed for 40 seconds with a light polymerizing appliance, (Ultralux, DabiAtlante, São Paulo, Brazil), with light intensity of approximately $480 \mathrm{~mW} / \mathrm{cm}^{2}$, gauged after every 10 samples using an analog radiometer (Gnatus, Ribeirão Preto, Brazil), after positioning the orthodontic accessory according to the manufacturer's instructions.

The samples were stored in $0.9 \%$ physiological serum for 24 hours, at ambient temperature, before being submitted to the shear bond strength test.

A universal test machine (EMIC, Model DL 2000, Equipamentos e Sistemas de Ensaios Ltda, Brazil) was used, connected to a computer to record the debonding forces. The test machine was calibrated with a $50 \mathrm{~N}$ load cell at a speed of $0.5 \mathrm{~mm} / \mathrm{min}$, according to the previously established methodology (6). 
After the orthodontic accessories were debonded the test specimens were photographed with a digital camera (Canon T1I Rebel, Canon Corporation, Japan), with a 105 mm macro lens and circular flash, and the images were transferred to a computer.

The images were evaluated and classified as regards type of failure resulting from accessory debonding, according to the following description:

- Cohesive in porcelain (CP) - in the case of fractures or cracks in the porcelain surface;

- Adhesive to porcelain (AP) - in the case when there was no failure in porcelain, or resin remainder on the porcelain surface, and all the resin was retained on the base of the orthodontic accessory;

- Cohesive in resin $(\mathrm{CR})$ - in the case when there was a resin remainder on the porcelain surface and at the base of the orthodontic accessory;

- Adhesive to the orthodontic accessory (AO) - in the case in which all the resin was adhered to the porcelain, without any remainder on the orthodontic accessory. Analysis of the entire sample was performed by one and the same evaluator, who did not know which group was being analyzed, characterizing blind evaluation.

The nominal bond strength values were recorded in $\mathrm{MPa}$ and analyzed by means of descriptive statistics. Normality of distribution was verified with the Shapiro-Wilk test with the statistical software SPSS (Statistical Package for Social Sciences) version 18.0. Once non-normal distribution was verified, the fracture strength data were compared among the four different experimental groups by using Kruskal-Wallis test. Afterwards the groups were compared in pairs by means of the Mann-Whitney test.The level of significance was set at $5 \%$ for all tests.

\section{Results}

Descriptive statistics are displayed in Table 1. The groups treated with silane bond agent obtained statistically higher bond strength values than the groups with similar acid etching in which this product was not applied.Group 1 showed statistically lower results, and Group 4 presented statistically higher results than the other tested groups.Groups 2 and 3 showed statistically equal performance, although Group 3 presented a higher standard deviation value, indicating that the technique provides a poorer standardization of results.

Table 1. Mean and standard deviation for shear bond strength and differences among experimental groups.

\begin{tabular}{ccc}
\hline & Mean & Standard Deviation \\
\hline G1 & $2.21_{a}$ & 1.47 \\
G2 & $7.24_{b}$ & 0.96 \\
G3 & $7.32_{b}$ & 3.70 \\
G4 & $21.93_{c}$ & 6.30 \\
\hline
\end{tabular}

Different letters indicate statistically significant differences $(\alpha=0.05)$.
The results of debonding failure analysis are shown in Table 2. No sample presented cohesive failure in resin, or adhesive failure between resin and the orthodontic accessory base.The groups in which the porcelain surface was etched with phosphoric acid presented exclusively adhesive failures between porcelain and resin. The groups that were submitted to surface etching with fluorhydric acid application, with and without silane application, presented $90 \%$ and $65 \%$ of cohesive failures in porcelain, respectively.

Table 2. Frequency of debonding failures in the studied groups ( $n=20 /$ group).

\begin{tabular}{ccccc}
\hline \multirow{2}{*}{ Treatment } & \multicolumn{4}{c}{ Types of failures (\%) } \\
\cline { 2 - 5 } & CP & AP & CR & AO \\
\hline G1 & 0 & 100 & 0 & 0 \\
G2 & 90 & 10 & 0 & 0 \\
G3 & 0 & 100 & 0 & 0 \\
G4 & 65 & 35 & 0 & 0 \\
\hline
\end{tabular}

\section{Discussion}

Some authors have suggested that the ideal rupture force for clinically successful orthodontic bonding is between 5.9 and 7.9 $\mathrm{MPa}(7,8)$. From analysis of the data obtained in the present study, it was observed that the maximum rupture force varied according to the ceramic surface treatment performed.In Groups 2 and 3 the mean rupture force obtained is in agreement with the value the literature relates as being adequate.

The use of phosphoric acid with silane did not provide bond strength capable of maintaining the bond successfully. On the other hand, the association with silane as bond agent was shown to be capable of increasing bond strength to an adequate level. This result corroborates those of studies mentioned in the literature, in which silane is known to be a bond agent capable of intensifying the retention of orthodontic accessories to various surfaces $(9,10)$. Silane reacts with the silica in porcelain and with organic groups of the resin, thus forming a chemical bond between the two materials (11).

In the group in which surface etching was performed with fluorhydric acid without silane, the mean rupture force was similar to that obtained using phosphoric acid and silane, however, the use of fluorhydric acid requires adequate isolation to protect tissues from its toxic effect.Its improper use is capable of causing innumerable traumas in soft tissues and tooth structures (10).

In Group 4 a significantly higher mean rupture force was obtained than that obtained in Groups 1, 2 and 3. Nevertheless, there is no need for such an intense force in order to obtain an adequate bond of orthodontic accessories (7). Added to this, the high incidence of cohesive failures in Group 4 showed that the treatment with hydrofluoric acid followed by saline may be inadequate in clinical practice. Some authors have suggested that as the bond strength is 
increased, the trend towards the development of cohesive failures also increases (12), a fact that could be confirmed by the data of this research.

Taking into consideration that the mean rupture force obtained in Group 4 was significantly higher than that considered desirable, and that it was significantly lower in Group 1, it may be observed that the force recommended as being ideal was achieved only in Groups 2 and 3. Thus, phosphoric acid associated with silane may be considered an efficient porcelain surface treatment, since fluorhydric acid has shown to be toxic to tissues. The results of the present study are in agreement with recent researches, in which it was shown that the use of phosphoric acid followed by silane application for bracket bonding to porcelain presented lower bond strength when compared with the use of fluorhydric acid with silane (13).

Moreover, when the orthodontic accessories were debonded in the samples in Groups 2 and 4, cohesive failures in porcelain were observed. Herion et al. (5) obtained similar results, in which the use of fluorhydric acid followed by silane application significantly diminished the brightness and altered the color of the porcelain surface after bracket debonding.

With regard to failures, those of the adhesive type, which occur at the adhesive/porcelain interface, are considered more desirable because they do not leave residues on the surface where bonding occurred (1). Contrary to some studies, such as the one conducted by Zachrisson et al. (14) which surface treatment with fluorhydric acid presented failure of the adhesive type, in the present study, there were $65 \%$ cohesive failures observed in Group 4 (fluorhydricacid+silane), showing that the treatment with fluorhydric acid and silane, although efficient as regards bond strength, did not provide satisfactory results as regards the type of debonding failures. The presence of this same type of failure was also observed in Group 2, in which the surfaces were etched with fluorhydric acid without the presence of silane, showing that although the bond strength in this group was within the ideal limits, the high presence of cohesive failures makes its use unfeasible, because after debonding orthodontic accessories, followed by polishing, porcelain is expected to return to its natural state as regards color brightness and texture. In addition, Andreasen and Stieg (15) suggested that silane of itself could only cause cohesive failures at the porcelain surface.
In the present study it was observed that silane increases the bond strength and not the occurrence of cohesive failures. It was observed that cohesive failures occurred when porcelain was treated superficially by etching with fluorhydric acid, with or without the presence of silane. Moreover, in the groups treated with phosphoric acid, with or without silane, the failures observed were $100 \%$ adhesive. In Group 1, although ideal as regards failures, it was not acceptable as regards bond strength. Whereas Group 3, in which silane was added to treatment with phosphoric acid, satisfactory results were obtained, both as regards the presence of failures and bond strength.

This study has some limitations that may preclude the extrapolation of the results: it is an in vitro study, which tested only resistance to shear forces, under constant load, without subjecting the sample to superficial aging or any simulation of the oral environment.Taking into consideration these limitations, the authors suggest that further researches should be conducted so that a reliable clinical protocol can be established, and one that presents therapeutic predictability, both with regard to the quality of orthodontic treatment and maintenance of the materials used in prosthetic rehabilitations.

\section{Conclusions}

The results of the present study suggest that:

- Silane application significantly increases the shear bond strength of orthodontic accessories to porcelain surfaces;

- Etching the porcelain surface with phosphoric acid alone does not provide adequate shear bond strength, capable of resisting the forces applied during orthodontic treatment;

- Surface etching with fluorhydric acid, with or without silane application, increases the occurrence of irreversible failures in porcelain;

- Surface etching with phosphoric acid, followed by silane application provided adequate bond strength, capable of resisting the forces applied during orthodontic treatment, without causing irreversible failures in porcelain.

Therefore, the use of phosphoric acid followed by silane application seems to be an optimum protocol for bonding orthodontic accessories to porcelain surfaces.

References 1. Mattos AM, Cappelli JM.Porcelain surface evaluation after debonding of orthodontic brackets. Rev Dent Press Ortodon Ortopedi Facial 2006;1 1:151-8.

2. Henriques ACG, Da Costa DPTS, Barros KMA, Beatrice LCS, Menezes Filho, PF. Dental ceramics:current aspects, properties and indications. Odontol Clín-Cient 2008;7:289-94.

3. Raptis NV, Michala KX, Hirayama H. Optical behavior of current ceramic systems. Int J Periodontics Restorative Dent 2006;26:31-41.

4. Yadar S, Upadhyay M, Borges GA, Roberts WE. Influence of ceramic (feldspathic) surface treatment on the micro-shear bond strength of composite resin. Angle Orthod 2010;80:577-82 
5. Herion DT, Ferracane JL, Covel DA. Porcelain surface interactions and refinishing after use of two orthodontic bonding methods. Angle Orthod 2010;80:167-74.

6. Fox NA, McCabe JF, Buckley JG. A critique of bond strength testing in orthodontics. Br J Orthod 1994;21:33-43.

7. Haydar B, Sarikaya S, Cehreli ZC. Comparison of shear bond strength of three bonding agents with metal and ceramic brackets. Angle Orthod 1999;69:457-62.

8. Newman GV, Newman RA, Sun BI, Ha JL, Ozsoylo SA.Adhesion promoters, their effect on the bond strength of metal brackets. Am J Orthod Dentofacial Orthop 1995; 108: 237-41.

9. Bishara SE, Von Wald L, Olsen ME, Laffoon JF. Effect of time on the shear bond strength of glass ionomer and composite orthodontic adhesives. Am J Orthod Dentofacial Orthop 1999; 1 16:616-20.

10. Larmour CJ, Bateman G, Stirrups DR. An investigation into the bonding of orthodontic attachments to porcelain. Eur J Orthod 2006;28:74-7.

11. Abu Alhaija ES, Abu Al Reesh IA, AI Wahadni AM. Factors affecting the shear Bond strength of metal and ceramic brackets bonded to different ceramic surfaces. Eur J Orthod 2010;32:274-80.

12. Giannini $C$, Francisconi PAS. Resistência à remoção de braquetes ortodônticos sob ação de diferentes cargas contínuas. R Dental Press Ortodon Ortop Facial 2008;33:50-9.

13. Ajlouni R, Bishara SE, Oonsombat C, Soliman M, Laffoon J. The effect of porcelain surface conditioning on bonding orthodontic brackets. Angle Orthod 2005;5:858-64.

14. Zachrisson YO, Zachrisson BU, Buyuklyilmaz T. Surface preparation for orthodontic bonding to porcelain. Am J Orthod Dentofacial Orthop 1996;109:420-30.

15. Andreasen GF, Stieg MA. Bonding and debonding brackets to porcelain and gold. Am J Orthod Dentofacial Orthop 1988;93:341-5. 